\title{
LA EXPULSIÓN DE LOS LECTORES DOMINICOS DEL CONVENTO DE SANLÚCAR DE BARRAMEDA, EN $1774 .^{1}$
}

POR

\author{
SALVADOR DAZA PALACIOS
}

Doctor en Historia

\section{RESUMEN:}

En el marco del difícil proceso criminal abierto contra el fraile carmelita Pablo de San Benito en Sanlúcar de Barrameda, en 1774, la justicia del rey Carlos III, encarnada por el alcalde mayor Roque Marín, deberá hacer frente también a las graves y fuertes presiones que ejercerá el estamento eclesiástico de la ciudad gaditana con el fin de desautorizarle y menoscabar su poder y sus deseos de controlar la disciplina religiosa y las frecuentes discordias existentes, principalmente en la Orden de Santo Domingo. Todo ello se saldará con la expulsión de los lectores de Teología del convento dominicano sanluqueño por orden del Consejo de Castilla y refleja un sombrío panorama, en plena llustración, de graves conflictos internos en el seno de las órdenes religiosas españolas.

\section{PALABRAS CLAVE:}

Sanlúcar de Barrameda; Andalucía; dominicos; lectores; escuela de artes y teología; arzobispo de Sevilla; Francisco de Solís; Roque Marín Domínguez; justicia eclesiástica; conflicto de jurisdicción; procesos criminales contra eclesiásticos; corrupción y relajación de costumbres; órdenes religiosas; Pedro Rodríguez Campomanes; Consejo de Castilla; rey Carlos III; Ilustración; reformismo borbónico.

\footnotetext{
${ }^{1}$ Archivo Histórico Nacional (AHN), Consejos, leg. 904, n 17.
} 


\section{THE EXPULSION OF THE READERS OF THE DOMINICAN CONVENT OF SANLÚCAR DE BARRAMEDA, IN 1774}

\section{ABSTRACT:}

Under the difficult process criminal case against the Carmelite friar Pablo of San Benito in Sanlucar de Barrameda, in 1774, justice of King Charles III, played by the mayor Roque Marín, must also face the serious and strong pressures exercise the ecclesiastical establishment of this city of Cadiz in order to disavow and to undermine his power and his desire to control the huge loss of religious discipline and frequent disagreements exist, mainly in the Dominican Order. This resulted in the expulsion of the readers of Theology of the Dominican convent of Sanlúcar by order of the Council of Castile and reflects a grim picture in full Enlightenment, serious internal conflicts within the Spanish religious orders.

\section{KEYWORDS:}

Sanlúcar de Barrameda; Andalusia; Dominicans; readers; school of arts and theology; Archbishop of Seville; Francisco de Solis; Roque Marín Domínguez; ecclesiastical justice; conflict of jurisdiction; criminal proceedings against ecclesiastical; corruption and relaxation of customs; orders religious; Pedro Rodriguez Campomanes; Council of Castile; King Charles III; Enlightenment.

$\begin{array}{ll}\text { Recibido/Received } & 07-01-2010 \\ \text { Aceptado/Accepted } & 24-04-2014\end{array}$

Paralelamente a la causa criminal seguida por la justicia real contra el carmelita descalzo fray Pablo de San Benito en la ciudad gaditana de Sanlúcar de Barrameda, en 1774, se produjeron una serie de incidentes gravísimos entre el estamento eclesiástico y la autoridad judicial de la ciudad, representada por su alcalde mayor, Roque Marín Domínguez. ${ }^{2}$ Estos incidentes se sumaron al clima de enorme tensión que existía en

${ }^{2}$ Este proceso ha sido estudiado por Salvador DAZA PALACIOS y María R. PRIETO CORBALÁN, Proceso criminal contra fray Pablo de San Benito en Sanlúcar de Barrameda. Univ. de Sevilla, 1998. Puede también verse, de los mismos autores, "La justicia en la época de Carlos III a través de un célebre proceso criminal", en Archivo Hispalense, n² 241, 1996, pp. 47-67, así como "El proceso contra fray Pablo de San Benito en Sanlúcar de Barrameda, primer proceso de la justicia civil española contra un eclesiástico homicida". En III Jornadas de Castilla-La Mancha de Investigación en Archivos: La Administración de Justicia en la Historia de España, Actas. Guadalajara 1999. T, I, pp. 119-140. 
España entre la Iglesia y el Estado en los años posteriores a la expulsión de los jesuitas. $\mathrm{Y}$, en el caso de la orden dominica, al gran deterioro sufrido tras el gran escándalo nacional ocasionado en 1768 cuando, en la ciudad extremeña de Llerena, cuatro frailes mataron a su prior con premeditación y alevosía. ${ }^{3}$

Una de las instrucciones que Roque Marín — juez instructor del proceso contra fray Pablo, el carmelita homicida- recibió del Consejo de Castilla, se refería a la "aprehensión de armas prohibidas" en el convento de carmelitas y en el convento de Santo Domingo de Sanlúcar de Barrameda. ${ }^{4}$ Fue el 27 de mayo de ese año de 1774, el día en el que, plenamente inmerso en la complicada causa contra fray Pablo, el alcalde mayor de Sanlúcar se dirigió a su interlocutor en el Consejo, el eminente y poderoso fiscal Pedro Rodríguez Campomanes, para enviarle el ramo separado que con tal motivo había formado. ${ }^{5}$ En él, le daba cuenta de los sucesos ocurridos en el convento del Carmen y le confesaba a Campomanes que no había querido seguir adelante con la investigación sobre los dominicos por temor a que el Consejo le desautorizase, pero se mostraba confiado en que si este órgano le avalase podría conseguir "justificar al por menor el asunto".

El Consejo de Castilla se hizo eco del envío del alcalde mayor de Sanlúcar el 2 de junio, día festivo en Madrid, y su gobernador, Ventura Figueroa, ordenó que el expediente pasase a los fiscales. Al día siguiente, éstos, con Campomanes a la cabeza, dictaminaron que era necesaria "una rigurosa providencia, para desterrar de las comunidades religiosas el abuso de las armas prohibidas". Una de las razones de esta opinión tan tajante era la verosimilitud, presentada por el mismo alcalde, sobre la existencia de armas también en el convento de los carmelitas

3 Salvador DAZA PALACIOS: "Acontecimientos extraordinarios en la ciudad de Llerena (1768-1773)". Revista de Estudios Extremeños, LVI (MayoAgosto 2000), 523-542. Este caso estará muy presente en lo acaecido en Sanlúcar pocos años después.

4 Por Carta Orden fechada en Madrid el 29 de Abril de 1774.

5 Sobre Campomanes existe una numerosa bibliografía. Valgan estos ejemplos como compendio de ella: José Antonio FERRER BENIMELLI (Ed.): Relaciones Iglesia-Estado en Campomanes. Madrid, 2002. Vicente LLOMBART ROSA: Campomanes, economista y político de Carlos III, Madrid, 1992. También resulta interesante el capítulo "Campomanes y los preliminares de la desamortización eclesiástica", de Francisco TOMÁS Y VALIENTE, en su obra Gobierno e instituciones en la España del Antiguo Régimen. Madrid, 1982, pp. 287-316. 
descalzos, aprendidas por el juez, que intervino dos pistolas y cuatro cuchillos. ${ }^{6}$

Debía realizarse un registro del convento de Santo Domingo para corregir estos abusos que podían traer fatales consecuencias a la seguridad pública. Según los fiscales, también debían formalizarse estas diligencias de aprehensión de armas, como se hizo en el caso de los carmelitas, dando cuenta al cardenal arzobispo de Sevilla, para que éste ordenase a su vicario de Sanlúcar que contribuyera "al logro de estas diligencias".

El Consejo, ${ }^{7}$ tres días más tarde, bajo la presidencia de Ventura Figueroa, decide, además, que se le devuelva al alcalde mayor de Sanlúcar la sumaria original que había remitido para que la prosiguiera. Asimismo, mandan los del Consejo a Roque Marín que lleve a cabo la justificación que ofrecía en su escrito, con la advertencia de que debía guardar el necesario y preventivo sigilo "y las demás precauciones oportunas para la perfecta averiguación" de los hechos. Una vez resuelta la indagación debía dar cuenta al Consejo con una copia de los autos.

\section{INFORME DE ROQUE MARÍN.}

Algo más de tres semanas necesitó Roque Marín para elaborar con todo detalle su informe sobre este oscuro asunto. Refleja un gran esfuerzo de investigación, pues las órdenes religiosas creaban a su alrededor un muro casi infranqueable para una autoridad civil que quisiese averiguar algo sobre ellas. El documento, de gran fuerza descriptiva, se propone informar al Consejo sobre "las personas de privilegio que, valiéndose de él, usan de armas prohibidas". Una "particularidad" que, para el alcalde, emana de la causa criminal en la que está entendiendo contra fray Pablo de San Benito. A pesar de haber practicado "las más sigilosas y extrajudiciales diligencias" para confirmar plenamente los "desórdenes acaecidos en el convento dominicano", no había podido conseguirlo por haberse encontrado con muchas $e$ importantes dudas.

La primera duda era si sería "inexcusable la asistencia del vicario eclesiástico", Rodrigo Pérez Viadas, para toda la justificación del procedimiento judicial, ya que su presencia perjudicaría al secreto que el Consejo le había recomendado con énfasis. Porque, al tener que informar al vicario sobre la investigación, se malograría "una justificación

${ }^{6}$ Vid. DAZA-PRIETO, Proceso criminal contra fr. Pablo pp. 92-93, 108, 141 y 143 , entre otras.

7 Integrado en esta sesión por Miranda, Ávila, Valiente, Velasco, Azpilcueta y Acedo. 
que se presenta relevante".

Roque Marín recela y desconfía del vicario porque era, "entre otras cosas, connotado ${ }^{8}$ de algunos religiosos dominicanos" que podrían resultar "reos de alguna gravedad". Y estaba, por su carácter sacerdotal y corporativista, unido interna e íntimamente con ellos. Así que el vicario podría incumplir el secreto sumarial y frustrar la comprobación de los hechos. Como juez reconoce que no tiene pruebas para acreditar esta desconfianza, pero la considera suficientemente acreditada por la actuación partidista de aquél en la causa criminal contra fray Pablo. ${ }^{9}$

Roque Marín añade que "los excesos cometidos por los padres lectores ${ }^{10}$ del convento dominicano (confederación y sublevación contra sus prelados, uso de armas y otros gravísimos desórdenes)" habían sido cometidos "intra claustra". Así que era indispensable interrogar al prior recién cesado y a otros religiosos para lograr "la sólida justificación de estos delitos". La conducta de aquél y de éstos, procurando con todo su esfuerzo someter a los lectores a la disciplina de la comunidad, les tenía sumidos "en la última fatiga".

El alcalde asegura que estos frailes, "observando su instituto", habían hecho todo lo posible por contener las desobediencias de los lectores, que era el origen del conflicto. Habían procurado "exterminar" sus nocivas costumbres de salir "solos y muy a deshoras", para que no tuvieran lugar "los escándalos públicos" que habían causado a los seglares, "de noche y de día". Algunos ciudadanos se habían sentido insultados e incluso alguno corrió el peligro de haber muerto a manos "de estos propios lectores, confederados contra su propia cabeza".

Debido a la extrema gravedad de la situación, los prelados dominicos habían comunicado "estos desórdenes a sus superiores, hasta llegar al mismísimo padre general de la Orden en la Corte Romana", Joan Thomas de Boxadors. ${ }^{11}$ Estos afligidos superiores habían

${ }^{8}$ Connotado: Relacionado, pariente lejano.

9 El vicario fue autorizado por el Consejo de Castilla a presenciar las declaraciones tanto del reo homicida como de los testigos eclesiásticos del proceso.

10 Lector: El encargado de enseñar Filosofía, Teología o Moral, en las comunidades religiosas.

11 La respuesta que dio el padre general está recogida en S. DAZA PALACIOS: Acontecimientos extraordinarios... Art. Cit, p. 540. Sobre Boxadors puede verse: Jean SARRAILH: La España ilustrada de la segunda mitad del siglo XVIII, Madrid, 1992, pp. 203-204. 
reclamado repetidas veces al alcalde mayor que remediara "unos procedimientos tan poco religiosos de sus propios hermanos". Últimamente, habían "practicado los más ardientes oficios para extinguir esa turba de confederados" cuyas intenciones sólo se dirigían a obtener "un reprensible libertinismo", que causaba entre los seglares "de ambos sexos un horroroso e inaudito escándalo, del que, emposesionados (sic) estos lectores, subsisten en el día sin Dios, sin Ley, sin Religión, sin obediencia, y sin prelado". Y sin el temor que les deberían causar las justas resoluciones del Consejo. ${ }^{12}$

Si se enumeraran los excesos con que procedía la Escuela dominicana constituiría una "mole interminable y un fastidio". Los lectores se habían ganado el favor del actual provincial, habían "despojado de su oficio al prelado que los contenía" y habían nombrado como prior "a uno de la propia Escuela que les consentía el desenfreno y que a todas horas del día y de la noche se estén advirtiendo públicos escándalos" y otros delitos de variada naturaleza. ${ }^{13}$

El informe describe la muy irregular conducta de los frailes de Santo Domingo, sublevados contra el suprior fray Francisco Galisteo, un religioso íntegro, prudente y de una conducta intachable, que intentó contener los desórdenes y escándalos de los lectores. ${ }^{14}$ Pero le trataron

12 Ya en 1758, cuando redactó sus Fundaciones de todas las iglesias, conventos y ermitas de Sanlúcar de Barrameda (Sanlúcar, 1995, p. 217), el historiador ilustrado Juan Pedro VELÁZQUEZ GAZTELU, constató la gran decadencia a la que había llegado el convento dominicano: "Ya no se encuentran en él aquellos grandes maestros, aquellos insignes predicadores y catedráticos, ni aquellos modelos de las más severa virtud... Y de esto nace la indulgencia en los superiores, la relajación en la observancia regular y la carga molesta e insufrible del público".

${ }^{13}$ Los prioratos de los dominicos gozaban de cierta autonomía de la que carecían los conventos de las demás religiones. Los mismos frailes elegían a su padre prior, de dentro o fuera de la comunidad, y el padre provincial confirmaba el nombramiento. Este espíritu de democracia interna llama la atención por su desafío al centralismo que gobernaba otras entidades religiosas, aunque ya podemos comprobar los graves perjuicios que ocasionó a la orden dominica. (Antonio CUESTA MENDOZA: Los dominicos en el Puerto Rico Colonial, 1521-1821. México 1946, p. 150).

${ }^{14}$ Sin embargo, no era el primer conflicto que sufría Galisteo, pues en su viaje misional a California, unos años antes, debió someterse a un expediente que intentó separarlo -junto a fray Miguel Hidalgo- de la provincia de Santiago, por graves desavenencias y tensiones provocadas desde su llegada a las tierras americanas. Galisteo e Hidalgo, tratados como disidentes, apelaron al virrey, que optó por derivar el conflicto a la propia Orden de Predicadores (Albert Bertrand NIESER: Las fundaciones misionales dominicas en Baja California, 1769-1822. Universidad Autónoma de Baja California 1998, pp. 30-31). 
con vilipendio, lo insultaron y cometieron con él "algún exceso de los del último grado".

Los lectores, con "informes siniestros", se ganaron al padre provincial y le convencieron para que quitara al superior. Le depusieron "con perjuicio de su estimación" y le sustituyeron por otro que toleraba "lo que es intolerable". Y así seguían. Se habían convertido en "el objeto escandaloso del pueblo, cuando, por su Instituto y Religión”, debían ser el centro de todas "las veneraciones".

Hubo una excepción: el lector habitual de Teología, fray Dionisio Ximénez, que se había opuesto a estos escándalos. Era un individuo "justo y docto", y ocupado diariamente de su oficio de misionero apostólico. Un fraile tan retirado, al que solo se le veía en la calle cuando iba a predicar a la Plaza. ${ }^{15}$ Un sujeto tan recomendable que atraía toda la atención de la ciudad "por su abstracción y su conducta religiosa" y que su propia exterioridad manifestaba visiblemente "lo ajustado de su proceder", pues, como hijo de Sanlúcar y de su propio convento, ${ }^{16}$ había procurado, desde hacía siete años, que se observasen las reglas de su profesión y que se contuviesen los desacatos cometidos por los lectores. Pero éstos, "por raros conductos", habían ganado la confianza de su provincial y no solamente habían depuesto al suprior presidente, sino que habían logrado separar del convento "al citado fray Dionisio Ximénez, confiriéndole un priorato en la villa de Aracena".

Esta resolución del provincial, según el alcalde mayor, era inaudita, pues daba margen a que los lectores quedaran "a sus arbitrios" para continuar sus desórdenes aún "con más libertinaje". Pretendían expulsar del claustro a estos dos rectos monjes -Galisteo y Ximénez- para así poder "violarlo con más frecuencia y practicar las incontinencias más

${ }^{15}$ Sin embargo, Cuesta Mendoza opina que la labor pedagógica de los lectores era de tanta importancia, que no se les permitía distraerse en otras ocupaciones, ni siquiera en la predicación. (Antonio CUESTA MENDOZA, Op. Cit, p. 83)

16 El dominico siempre conservaba la afiliación al convento donde ingresara, así lo hicieran prior o provincial o pasara a Indias. Así, el priorato dominico participaba de la estabilidad del monje y de la movilidad del fraile mendicante. Muchos prioratos seguían con amor a sus hijos en sus viajes por el mundo, con anotación de sus hechos y conmemoración de su muerte (Antonio CUESTA MENDOZA, Op. Cit., pp. 150-151). Coincide en su diagnóstico el alcalde mayor con el historiador ilustrado sanluqueño Velázquez Gaztelu, que achacó la decadencia de la Escuela dominica precisamente a haber sido confiada a frailes que no eran de Sanlúcar (J. P. VELÁZQUEZ GAZTELU: Fundaciones...., Op. Cit., p. 207) 
espantables". Querían perder de vista a aquellas personas que controlaban su comportamiento, dando lugar a una situación aún más funesta que la ocurrida con el carmelita descalzo, pues se temía el alcalde mayor que, cualquier día, "algún seglar, en defensa de su propio honor, tiña sus manos con la sangre de alguno de estos sacerdotes".

Para evitarlo, se necesitaba "como principal fundamento" el poder completar la relación de desórdenes y delitos que habían ocurrido en el convento dominico. Y para ello era indispensable que volvieran a él esos religiosos "de conocido juicio, especialmente los referidos fray Dionisio Ximénez fray Francisco Galisteo", ya que sin el testimonio de estos individuos no se podría cerciorar el alcalde de "unos excesos que fueron cometidos intra claustra". Porque los seglares, aunque tienen noticias de lo sucedido, "no pueden especificarlas con la verdad y pureza" que lo podría hacer "un prelado insultado, un religioso acometido y otros testigos fidedignos de lances tan extraordinarios". Pues en el caso de que no pudiera lograrse el regreso de fray Dionisio Ximénez, —como desearían sus enemigos - no podría tener efecto sólido "una justificación tan cuidadosa" como necesaria.

Roque Marín cierra su informe suplicando al Real Consejo una pronta solución para que "no queden impunes unos hechos que tanto perjudican a la República".

El juez acompaña la anterior representación con una carta personal dirigida al fiscal del Consejo, Rodríguez Campomanes, fechada el 8 de julio. Le confiesa que está "cercado de dudas" y reconoce que no tiene otra salvaguarda que su respaldo como fiscal, así que toda su preocupación se centra en avisarle para que, en el caso de que se tomara una resolución enérgica contra los dominicos, se le liberara a él de cualquier daño o desprestigio, ya que podrían atacarle enviando a Madrid algún informe negativo. Le sería "muy doloroso que, después de estar entendiendo en un servicio tan loable a Dios y al Rey", le perjudicase "la relación ${ }^{17}$ siniestra de un díscolo, por influjo temerario de un malcontento".

Campomanes, por el informe adjunto, podría comprobar con amplitud "el estado de los regulares dominicanos y la situación de su conventualidad", y los motivos por los que el alcalde pretendía conseguir "un nuevo beneplácito para lograr la justificación" completa de todos los desmanes referidos. ${ }^{18}$

17 Relación: Informe.

18 Estos hechos confirman y se suman al panorama general de relajación y decadencia de las órdenes religiosas que refleja William $\mathrm{J}$. CALLAHAN en Iglesia, poder y sociedad, 1750-1874, Madrid, 1989, pp. 30-34. 
El Consejo recibió el escrito el 18 de julio. Los señores Figueroa, Ávila y Valiente ordenaron su pase a los fiscales y éstos emitieron su parecer un día después.

\section{INFORME FISCAL Y ÓRDENES DEL CONSEJO.}

Dirigidos por Campomanes, los fiscales del Consejo determinan que el alcalde mayor debía proceder en todo "según las órdenes que ya tiene", sobreseyendo todo lo concerniente a los religiosos dominicanos "hasta nueva orden".

Optan por solicitar al cardenal arzobispo de Sevilla, Francisco de Solís, un detallado y completo informe sobre todo lo sucedido en el convento de Santo Domingo de Sanlúcar. El cardenal, "valiéndose de personas íntegras y de toda satisfacción", debía comunicar al Consejo sus indagaciones con el fin de que éste actuase en consecuencia. Así lo confirma el Consejo, presidido por Ventura Figueroa, asistido por Ávila, Valiente y Azpilcueta, que se reunió el jueves 21 de julio.

La carta enviada al arzobispo resume todo el informe de Marín textualmente, pero con mayor precisión y sin citar la fuente. La sorpresa del cardenal Solís no debió ser menor, pues se le expone en toda su crudeza el asunto, matizando el Consejo en su carta, dando crédito al juez en Sanlúcar, que todos los escándalos, desenfrenos y desórdenes producidos por los dominicos eran "justificables". ${ }^{19}$

\section{REPRESENTACIÓN DE ROQUE MARÍN A CAMPOMANES.}

Antes de que le llegara esta última resolución del Consejo, Roque Marín se puso de nuevo en contacto con el fiscal Campomanes el 26 de julio para manifestarle que esperaba con ansiedad la instrucción del Supremo tribunal, porque ya había expresado en su anterior escrito "los peligros" a los que se exponía "a la vista de tantos malcontentos regulares y seculares". Por eso, le recuerda su carta anterior sobre "los deformes motivos que tenía para impetrar su protección, a la vista de un asunto tan empeñoso, y en que me veía, como me veo, tan cercado de vidriosos proyectos...".

${ }^{19}$ El borrador de la carta (copia que se hacía en el Consejo de todas las que salían de su escribanía) contiene numerosas tachaduras y correcciones, sin duda por la dificultad que entrañaba explicar al arzobispo la cuestión con claridad, sin despertar más recelos que los precisos y buscando en él la colaboración animosa. 
A pesar de ello, Marín asegura a Campomanes que no tiene "el menor temor", y que los "incesantes movimientos" de los eclesiásticos sanluqueños no le podrían "aterrar la conducta". Porque los religiosos dominicanos, sin saber ni cómo ni por dónde, habían tenido conocimiento de la investigación que el Consejo le había encargado. A causa de ello, los rebeldes del convento estaban "confabulados" contra él. Ayudados por frailes de otras órdenes religiosas, hacía más de veinte días que estaban celebrando reuniones y juntas secretas casi diariamente. Estas reuniones se celebraban tanto en Santo Domingo como en La Merced,

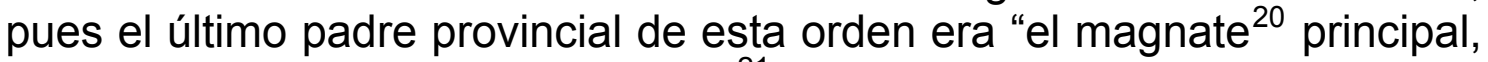
según se comprende públicamente". ${ }^{21}$

Este mercedario, por el cargo que ostentaba, tenía una gran capacidad de liderazgo y todos se habían unido a él, con subordinación con el fin de perturbar la conducta del juez y fomentar toda clase de

20 Magnate: Personaje muy ilustre y principal por su cargo y poder.

${ }^{21}$ Por Real Cédula se procedió a la reducción del número de religiosos de la Orden de mercedarios en todo el Reino, en este mismo año 1774. No se libró esta orden de la importante y efectiva operación comenzada por el Consejo de Castilla en los años posteriores a la expulsión de los jesuitas para "reducir la gran multitud de individuos conventuales" que no poseían suficiente dotación económica para su subsistencia. Al igual que en el resto de las órdenes, a los mercedarios se le asignó una dotación anual suficiente de 200 ducados por religioso. Una vez calculadas las rentas anuales de cada convento, se dividía en fracciones de esa cantidad y así se calculaba qué número real de religiosos podía mantener cada uno de los conventos de la Orden. Las "letras o decreto de reducción" de la Orden mercedaria en España estaba hecha por su general, fray Josef de San Bartolomé. Éste, para elaborar su decreto, recibió información, entre otros, del padre fray Miguel de San Ramón, provincial de Andalucía, que presentó una "relación o estado", formado por los comendadores de los respectivos conventos, sobre la renta que percibían, número de religiosos, entrada anual de ellos, costes de los cultos y fábrica, líquido que queda libre, etc. En el caso que nos ocupa, el convento de mercedarios de Sanlúcar, la renta anual declarada por su comendador ascendía a 34.526 reales. En el convento habitaban 23 religiosos, lo que calculado en proporción a los 200 ducados que se les había señalado a cada religioso, hacía que en este convento sobrasen 8 religiosos —sólo se podían mantener 15- y aún les quedaba 1.526 reales para otros gastos. En la Real Cédula se recuerda asimismo, por parte del Consejo, la observancia y cumplimiento que deben seguir todos los de la Orden de "no vaguear fuera de los conventos con ningún motivo". La Orden Real -y esto es lo interesanteestá firmada por el propio Carlos III, en San Ildefonso, el 28 de Julio de este mismo año de 1774. Justamente dos días más tarde que la representación de Roque Marín a Campomanes, en la que implica a los mercedarios descalzos en la conspiración dominica. (Biblioteca de la Universidad de Sevilla, Fondo Antiguo: Real Cédula de S.M. y señores de su Consejos..., Signatura 113/135). 
quejas por su actuación. ${ }^{22}$ Estos frailes calificaban de "delincuente" al alcalde mayor, pues no aceptaban que fuese el juez de fray Pablo de San Benito, el carmelita homicida. ${ }^{23}$ Estaban continuamente "gritando", sobre la violación que para sus privilegios e inmunidades suponía la causa criminal abierta contra el religioso reo.

Marín tenía su espíritu "cercado" y bajo una fuerte tensión, pues cualquiera de las contingencias del caso provocaban un chisme en el pueblo. El juez proseguiría con el procesamiento, pero temía que actuaran contra él presentando algún recurso al Consejo, dado el gran poder del cuerpo eclesiástico en la ciudad, especialmente los numerosos frailes y sus partidarios seglares, que intentaban por todos los medios desprestigiarlo con un continuo murmullo de bulos y mentiras y con las citadas reuniones secretas tanto de día como de noche.

Los lectores dominicos se encontraban expectantes y "temerosos" de que pudiese recaer sobre ellos una sentencia contraria a sus caprichos, pero sin embargo no cesaban "en la continuación de sus desórdenes". Porque no observaban "sumisión, reverencia ni otro efecto alguno de disciplina en su claustro". Y como carecían de prelado, recurrían continuamente al provincial para que éste les eximiese de la obediencia.

Su libertad había llegado a tanto que, sin más permiso que el del presidente que ellos mismos habían nombrado, había salido del pueblo hacía cuatro días "un lector dominicano (el principal motor de las inquietudes), a la ciudad de Écija, a tratar con su provincial sobre las sospechas pendientes" y sobre los recursos iniciados en el Supremo Consejo.

Estos mismos regulares habían hecho correr la voz de que el alcalde acabaría mal a causa de su rigurosa actitud "en el proceso criminal contra el carmelita descalzo". Pero Marín avisa de que este proceso sí habría sido del agrado de los dominicos si él no hubiese alterado el procedimiento acostumbrado en favor de la víctima.

Una segunda consideración que exponía Marín a Campomanes

${ }^{22}$ Ya veremos cómo el provincial de los dominicos se dirigió al Consejo de Castilla, una vez que conoció la resolución de este asunto, acusando al alcalde mayor de maquinación contra él, etc.

${ }^{23}$ Los prelados de las órdenes religiosas no podían aceptar que un juez civil procediera criminalmente contra un eclesiástico protegido por la inmunidad. 
era la gran necesidad y urgencia de una providencia rápida y efectiva del Consejo en este asunto. Porque las juntas que estaban celebrando los frailes de varias órdenes debían estimarse como "muy perjudiciales", pues estaban dirigidas contra él y pretendían convertirle en reo por defender la supremacía de la jurisdicción civil. Insiste en que mercedarios y dominicos se juntan unánimes en sus operaciones bajo el amparo de una misma ropa y con el asesoramiento jurídico del licenciado Máximo Zozaya, abogado del vicario "y declarado enteramente a favor de aquellas máximas". ${ }^{24}$ Las idas y venidas de este letrado entre La Merced y Santo Domingo eran constantes. Acudía lleno de intrigas a resolver gratis aquellas cuestiones que los eclesiásticos de ambos conventos maquinaban ocultamente y que el alcalde no había podido aún averiguar.

"Esto, señor, —dice Marín a Campomanes- es sumamente perjudicial para los asuntos pendientes; y mucho más a mí que, aunque logro la protección de vuestra señoría, que es la más alta, estoy constituido por enemigo público de estos regulares..."

Por último, Marín desea que conste ante el Consejo que la justificación de todos los pasajes comentados es casi imposible, ya que le han sido desvelados "por personas fidedignas, en calidad de amigos, con la condición de no ser descubiertos". Estas personas aducían que el juez, cuando cumpliese su mandato, -le restaba algo menos de un año-, se marcharía de la ciudad, pero ellos se quedarían y tendrían que seguir conviviendo con los frailes rebeldes que habían provocado toda la situación.

En el caso de intentarse la justificación de lo ocurrido, ésta no sería sólida, porque las noticias provenían "de unos a otros, dichas en las tertulias particulares". Los informadores no querían dar la cara, pues tenían miedo "de ser declarados por enemigos de los frailes, luego que fuesen descubiertos", lamentando el juez Marín una vez más la opresión que sufre a causa del juicio contra fray Pablo de San Benito:

"La razón fundamental que tienen los regulares y todos sus afectos para declararme como enemigo de ellos es que las resultas de la causa del regular carmelita se han hecho razón de Estado". ${ }^{25}$

Así que consideraban que el alcalde quedaría totalmente desprestigiado si la resolución del proceso le fuese adversa. Y para

${ }^{24}$ En efecto, Zozaya aparece desde el principio de la causa contra fray Pablo como asesor del vicario. (DAZA-PRIETO, Proceso criminal...p. 59)

${ }^{25}$ Atina bastante aquí Roque Marín, al haberse dado cuenta de la gran trascendencia política que estaba teniendo el proceso contra fray Pablo, al quedar bajo la atenta vigilancia de Carlos III, el Estado hecho carne. 
conseguir eso, los regulares sanluqueños deseaban obstinadamente perturbar el proceso y que, de esta forma, se sospechara de su conducta judicial y se mudase de mano el conocimiento de la causa. ${ }^{26}$

Para conseguirlo, "estos apasionados empeñarían sus propias vidas y perderían sus caudales", creyendo que así, "además de que el reo saldría impunido, quedaría yo bien escarmentado". Insiste Marín ante Campomanes que, "para resistir tan incesante batería" no tenía "otro antemural que el fiscal del Consejo, "cuyo superior conocimiento sirve a mi pequeñez de un escudo formidable que rechace y destruya en todas sus partes semejantes máximas". Y le urgía finalmente para que se pronunciara una resolución sobre este asunto, "para obedecerla ciegamente".

\section{NUEVO INFORME DE LOS FISCALES DEL CONSEJO.}

El Consejo recibe el envío el 3 de agosto, y ordena su pase a los fiscales con el siguiente resumen informativo: "El alcalde mayor de Sanlúcar de Barrameda representa las juntas que hacen los dominicanos y mercenarios, el desorden [de] los primeros y la coligación de unos y otros para apartarle de la causa de fray Pablo de San Benito por interés común, y pide se tome providencia por el Consejo".

Mientras esto no ocurría, Roque Marín no cesaba en sus diligencias. Tres días más tarde, el viernes, 29 de julio, redactó otro detallado Informe para el Consejo sobre la mudanza de conventualidad de los carmelitas sanluqueños que había solicitado el fiscal de la causa contra fray Pablo. El vicario había enviado también su informe al Supremo tribunal, sin que encontrase motivo alguno para tomar medidas contra el convento. Roque Marín se decanta claramente por las tesis del fiscal, pidiendo que se extinguiera la comunidad carmelitana de Sanlúcar, donde no hacía "ninguna falta". ${ }^{27}$

Los fiscales del Consejo, encabezados por Campomanes, emiten su dictamen el 18 de agosto. ${ }^{28}$ Responden a las dos cuestiones, la de los

26 Es decir, que la causa contra fray Pablo pasara a la jurisdicción eclesiástica.

27 Salvador DAZA PALACIOS, La fallida mudanza de los carmelitas descalzos de Sanlúcar de Barrameda (1774). Art. inédito. El informe de Roque Marín estaba incluido en este mismo legajo (AHN, Consejos, leg. 904) a pesar de que el asunto de los carmelitas tenía su propio expediente independiente del de los dominicos.

28 Incluido en DAZA / PRIETO, Proceso criminal contra fray Pablo..., en 
carmelitas y la de los dominicos. Respecto a éstos, los fiscales, en consonancia con la decisión ya tomada por el Consejo el 21 de julio, opinan que "...sobre la desavenencia entre los religiosos del convento de Santo Domingo, no conviene tomar providencia alguna hasta que el cardenal arzobispo de Sevilla evacue el informe que se le ha pedido". Tan sólo le ordenan al alcalde que finalice la causa contra fray Pablo de San Benito en un plazo de ocho días, así como que reciba información detallada sobre el nudo hecho por los carmelitas descalzos, con motivo de la causa. ${ }^{29}$

\section{INFORME DEL ARZOBISPO DE SEVILLA AL CONSEJO.}

Hasta el miércoles 31 de agosto no terminó Francisco de Solís el informe que el Consejo le había solicitado, cuyo contenido esperaban los fiscales y consejeros para tomar una providencia. ${ }^{30}$

El cardenal asegura que se había valido de personas de su entera confianza para informarse de la situación en que se encontraba el convento de Santo Domingo de Sanlúcar. Y había averiguado que "la confederación tumultuosa intra claustra, armas, desobediencias escandalosas y reprehensibles e insultos armados contra el propio prelado, por parte de los lectores de dicho convento", según se había denunciado ante el Consejo, habían sido "ponderaciones abultadas y aglomeración de voces ruidosas, procedidas de un malicioso artificio, y no hijas de una sincera verdad...".

"Lo únicamente cierto - dice el arzobispo- es que, habiendo cumplido el prior penúltimo por Enero de este año [de 1774], entró por presidente, según la Ley y Constituciones de la Orden, el suprior, que era el padre fray Francisco Galisteo, religioso ajustado y de conducta prudente". ${ }^{31}$

Éste, "en el tiempo de su presidencia, procuró que los religiosos viviesen con arreglo a sus sagradas constituciones y Leyes, lo que no agradó a los lectores, que hacen como una parte separada del resto de la comunidad". Porque "a título de sus cátedras, no se conformaban con este modo de pensar del presidente".

Galisteo, "movido de estas desazones que tenía con los lectores, o

la parte que se refiere a dicha causa.

${ }^{29}$ Vid. DAZA/ PRIETO, Proceso criminal..., pp. 205 y ss. y 208 (nota 6)

${ }^{30}$ Sobre este prelado puede leerse el corrosivo retrato que hace de él el ministro Azara con motivo de su asistencia al cónclave de 1769 (Jean SARRAILH, Op. Cit, pp. 634-635).

${ }^{31}$ Esta última expresión es la misma que utiliza el Consejo. 
de los afanes que le costaba la manutención de la comunidad", envió un escrito a su provincial, renunciando al cargo. ${ }^{32} \mathrm{El}$ provincial no accedió a su solicitud sino que "lo consoló con buenas palabras, hasta que por el mes de Abril [de 1774] nombró para prior de Sanlúcar a un religioso que ejercía el mismo oficio en Marchena". Este dominico, "a la fuerza de la obediencia", se presentó en el convento sanluqueño, dispuesto a afrontar su responsabilidad pero, "a los pocos días renunció al cargo", admitiéndole su renuncia el provincial. Por esta causa, volvió a ostentar la presidencia el suprior, fray Francisco Galisteo.

"Cargado éste [por] segunda vez con el oficio", hizo varias diligencias para poder sufragar a su numerosa comunidad. Marchó a Cádiz y allí consiguió que le diesen para su convento una limosna que alcanzó la cantidad de 400 ducados. Agradecido, "quiso mostrar su reconocimiento, y propuso a la comunidad, como medio oportuno para ello, el que se dijese una misa cantada y vigilia por el bienhechor" que había dado tan generosa dádiva. "Los lectores, tal vez estimulados del resentimiento que tenían con dicho presidente, respondieron que hiciese lo que gustase, pero sin contar con ellos", ya que, "por el servicio de sus cátedras, estaban exentos de cumplir estas cargas".

La negativa "la sintió mucho el presidente, y les replicó que si por sus cátedras estaban exonerados de la asistencia al Coro para el cumplimiento de dicha misa y aniversario", por lo mismo "estaban obligados a abstenerse de las salidas por las mañanas, por ser el tiempo destinado para los estudios". Y así, dispuso que por ningún motivo pudiesen salir a la calle en ese horario, aunque fuese con el fin de "ir a confesar a las religiosas de su orden", ${ }^{33}$ pues este cometido debían realizarlo por la tarde y volver después al convento "a una hora competente". Por este motivo, el pleito conventual siguió embrollándose aún más:

"Esta disposición del presidente disgustó tanto a los lectores que, por no pedirle licencia, se abstuvieron de salir aun para confesar a las monjas en las horas que les había insinuado".

32 Velázquez Gaztelu atribuye esta crisis económica conventual a la desaparición de las "crecidas limosnas" que les otorgaban antiguamente los duques de Medina Sidonia y los ingresos procedentes de los navegantes a Indias por el patronato de la Virgen del Rosario, cuyo tráfico y número había disminuido bastante (Fundaciones... Op. Cit., p. 217).

${ }^{33}$ Las madres dominicas del convento de Madre de Dios. 
Las madres dominicas empezaron a quejarse "de que no iban a darles el pasto espiritual". Los lectores, por su parte, enviaron distintos escritos al padre provincial. Mientras tanto, las monjas tomaron la decisión de proponer como mediador en el conflicto "al padre guardián del convento de San Francisco, quien, con sinceridad y sin cautela, pasó cerca del anochecer a Santo Domingo a promover su mediación entre el presidente y los lectores".

Ese mismo día celebraron una Junta todos los implicados en la que "hubo varias altercaciones por una y otra parte y algunas desconcertadas voces, en el ardimiento con que cada cual quería exponer sus razones". Pero en ningún caso hubo "demostración alguna de amenazas ni de malas palabras de unos a otros", asegura el arzobispo, sino que "todo el motivo del escándalo" provenía de que algunos vecinos percibieron desde fuera del convento "las voces" de la discusión, al durar la asamblea hasta las once de la noche. ${ }^{34} \mathrm{~A}$ esa hora, el guardián franciscano se retiró a su convento y entonces, probablemente, le vieron salir los mismos que habían percibido antes "los ecos de las voces" durante la larga discusión.

Esta "disputa" es "lo único notable" que había ocurrido en el convento de Santo Domingo. Francisco de Solís ${ }^{35}$ negaba categóricamente que en la reunión hubiese habido "armas, desobediencias atrevidas, ni otra confederación más que las desordenadas voces con que cada uno quería esforzar su parecer y dictamen". En ningún momento los lectores insultaron al prior Galisteo. "Este prudente religioso, viendo el disgusto con que estaban los lectores, -sigue contando el cardenal-, y que el guardián de San Francisco lo que únicamente había conseguido en su mediación con ellos era el que se presentase un recurso al padre provincial", volvió a presentar su dimisión a éste, que se la aceptó, "nombrando en su lugar al padre fray Avelino Ruiz, lector de Moral en el mismo convento" ${ }^{36}$

Este fraile era "un sujeto indiferente e imparcial, y de una vida notoriamente arreglada", dándose la circunstancia de que "jamás concurrió con los demás lectores en los sucesos acaecidos con el

34 Es decir, que si comenzó "al anochecer" y duró hasta las once de la noche, la junta duraría, al menos, cuatro horas.

35 Más adelante comprobaremos, por explicación del propio Solís, que no era lo único "notable" que había ocurrido en Santo Domingo.

${ }^{36}$ Avelino Ruiz recibió su primera ordenación el 25 de Marzo de 1757 en Sevilla, ante el obispo auxiliar Domingo Pérez de Rivera. En 1758 recibió el diaconado y hasta 1778 no fue examinado para confesor. (Ma Victoria BRIASCO URGELL y otros: Inventarium: dominicos andaluces, oficios $y$ ordenaciones. Málaga 1985) 
referido Galisteo".

De ello se podía deducir "la falsedad" de lo que se había denunciado al Consejo de que habían sido los lectores quienes habían quitado a Galisteo de su cargo y que tenían al provincial "a su contemplación". Constaba que el prior había presentado su renuncia por dos veces. ${ }^{37}$

Respecto al sometimiento del provincial al capricho de los lectores, nada más incierto, según Solís, pues "se colige que, habiéndole pedido algunos de ellos la licencia para ir a sus casas y tierras, por vía de descanso y desahogo", se las había denegado por tener "a su cuidado la dirección de las religiosas dominicas" a quienes no podían ni debían abandonar.

En cuanto al traslado de fray Dionisio Ximénez al priorato de Aracena, el arzobispo aclara que no había llegado a salir de Sanlúcar, pues, aunque era cierto que lo propusieron para dicho cargo, no llegó tomar posesión del mismo "o por su renuncia o por la falta que podía hacer en Sanlúcar por su arreglada conducta y buen ejemplo". ${ }^{38}$

El arzobispo Solís concluye su informe manifestando que el convento sanluqueño se encontraba por fin con un prior íntegro, prudente y capaz, según le habían asegurado, por lo que no había "que temer [que] suceda cosa notable". Sin embargo, "para precaver que en el futuro pudieran ocasionarse [nuevos] desazones con los priores o presidentes, sería muy oportuno y conveniente que los lectores que hoy hay [en la Escuela] se removiesen a otras partes, con el honor que les corresponde a su graduación. $Y$ que no se nombren otros en su lugar por no ser necesarios en aquella ciudad, mediante a que en ella pocos o ningunos estudiantes ocurren, y con un lector de Filosofía y otro de Teología Moral, habría bastante, y con sólo dos, poca parcialidad podrían fomentar" en el seno de la comunidad.

El arzobispo añade además un curioso caso ocurrido en 1768 en el mismo convento de Santo Domingo. Con su relato trata de justificar que la disputa entre los lectores y los priores dominicos venía de lejos: "En lo pasado, como de seis años a esta parte, hubo un prior llamado fray Miguel Caro $^{39}$ y un lector llamado padre Colmenero. ${ }^{40}$ Éste tenía una

${ }^{37}$ Cosa que no demuestra que su renuncia por dos veces no la hubiesen provocado los lectores.

${ }^{38}$ Contradice claramente aquí el arzobispo a Roque Marín.

${ }^{39}$ Miguel Caro recibió sus primeras órdenes en el convento de la Merced 
amistad que al prior no le parecía bien, y de la que lo procuró separar". Colmenero se resintió por ello "y adunado ${ }^{41}$ con los demás lectores, se le opusieron al prior, y con este motivo tuvieron disgustos de alguna gravedad". Los lectores presentaron un "recurso al General y, al mismo tiempo, le enviaron por correo al prior una carta sin firma", amenazándole de muerte, por las reprensiones que daba a Colmenero.

Pero todo esto "quedó en voces", pues a Colmenero "se lo llevó Dios y el prior continuó pacíficamente su oficio hasta que lo concluyó". Esta historia podría ser el origen de que se hubieran denunciado al Consejo insultos y amenazas de muerte contra el prior, piensa el arzobispo. ${ }^{42}$

el 2 de junio de 1730 de manos del obispo dominicano fray José Esquivel. En 1732 recibió el subdiaconado en el convento de las Capuchinas y el diaconado en 1733 en San Antonio Abad. (María Victoria BRIASCO DE URGELL: Ibidem)

40 Se trata de fray Juan Colmenero, que fue catedrático de Dialéctica (Summulas) en 1753, de Lógica en 1754, de Física en 1755, de Metafísica en 1756 y de Moral en 1760 y 1761. En 6 de mayo fue nombrado catedrático de Moral por ascenso de fray Francisco Posadas. Salió de la cátedra por haber cumplido el 1 de octubre de 1761. Defendió Conclusiones Generales en la Orden, presididas por el regente, fray Manuel Saavedra, en 1753. Presidió las Conclusiones en 1756 y en 1761. (BRIASCO DE URGELL: Ibidem)

41 Adunar: Congregar, juntar, unir. Unificar, reducir varias cosas a una sola.

42 Desde luego, la situación interna de la orden dominica no era nada serena. Recordemos las continuas referencias que fray Pablo de San Benito hizo en sus declaraciones, con relación al famoso crimen cometido por los dominicos de Llerena (Badajoz), que asesinaron a su prior, precisamente. (Ver DAZA / PRIETO, Proceso criminal contra fray Pablo.., pp. 82 y 86 y Salvador DAZA PALACIOS, Acontecimientos extraordinarios...) Puede verse, igualmente, sobre la gran crisis de la orden dominica, a niveles generales, en el último cuarto del siglo XVIII el interesante trabajo de Álvaro HUERGA: Los dominicos en Andalucía. Sevilla 1992, pp. 203 y ss. 


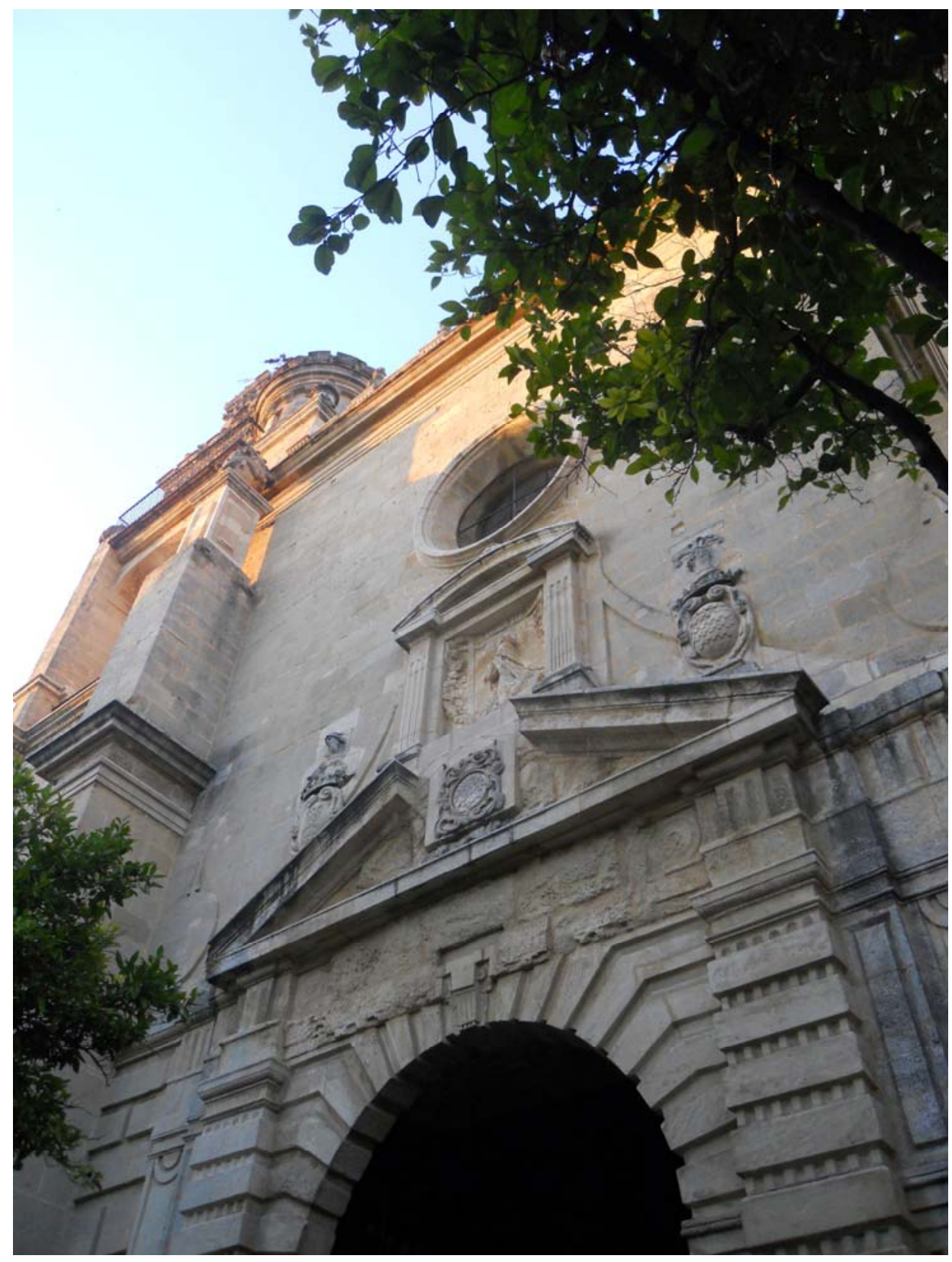

Figura 1. Fachada de la iglesia conventual de santo Domingo de Guzmán Sanlúcar de Barrameda (Fotografía del autor)

TERCER INFORME DE LOS FISCALES DEL CONSEJO.

Los consejeros reciben el Informe del arzobispo el 7 de septiembre y encargan su dictamen a los fiscales. Campomanes y sus colegas interpretan que, según lo manifestado por el arzobispo Solís, la indisposición que tenía la comunidad dominica se vio agravada por haber querido mediar el padre guardián de San Francisco y que, "habiéndose en aquel intermedio proveído al convento de un prior íntegro y de 
conocida prudencia y capacidad", están "más sosegados los lectores". Y que aunque el cardenal piensa que no podrían ocurrir más "cosas notables", sería una buena medida de precaución el traslado de los padres lectores a otros conventos, dejando en Sanlúcar tan sólo a dos.

Esta solución parecía "la más acertada y oportuna" para extinguir del convento "la parcialidad entre sus religiosos y las inquietudes y desobediencias a sus priores". Porque el que los lectores, que se erigen "como maestros de los demás", sean precisamente "los díscolos y piedras de escándalo", se debe "al abuso de distinciones que exigen en las comunidades, de lo que resulta el orgullo y el espíritu de independencia" de los que hacen tanto alarde.

Así pues,

“...aunque al Consejo no le consta, como debiera, la reducción del número y arreglo de los dominicos hecho por su actual General, ${ }^{43}$ si el Consejo lo tiene a bien, podrá mandar que se escriba carta acordada al provincial de la orden dominica de Andalucía, para que disponga con la mayor brevedad mudar a otros conventos de la provincia a dichos lectores, y que así, removidos y dispersos, se averigüe su conducta, se castigue y se dé cuenta al Consejo de la resulta. Poniendo solo en el convento de Sanlúcar, conforme expone el arzobispo, un lector de Filosofía y otro de Teología Moral, que sean imparciales y de otra conventualidad. ${ }^{44}$ Excusando enviar lectores para otras enseñanzas que allí no son necesarias".

Dan su parecer finalmente los fiscales sobre la conveniencia de que esta resolución se le comunique al arzobispo de Sevilla y que se le manifieste la satisfacción del Consejo por su celo, haciéndole "particular encargo de que esté a la vista de lo que ocurra, en uso de sus facultades ordinarias, y avisando al Consejo sobre lo que crea y necesite de especial protección". Apenas una línea le dedican los fiscales al eficaz e intranquilo Roque Marín: "También convendrá enterar de esta providencia al alcalde mayor de Sanlúcar...".

${ }^{43}$ Ya hemos dicho que el Consejo llevó a cabo en los años posteriores a la expulsión de los jesuitas un operación de reducción de efectivos conventuales, adaptándose a los niveles reales de renta con los que podrían autoabastecerse. Nos consta que se llevó a cabo entre los trinitarios (1769), carmelitas calzados (en 1771), mercedarios calzados y descalzos (1774). También se reformaron algunos de sus planes de estudios.

44 Esto último significaba que se expulsaría a todos los lectores que residían en Sanlúcar. 


\section{LA EXPULSIÓN DE LOS LECTORES.}

La sala primera del Consejo, ${ }^{45}$ reunida el viernes 9 de Septiembre, acuerda que "en conformidad de lo que informa y propone el arzobispo, se comuniquen las órdenes y avisos que dicen los señores fiscales. $Y$ que esta providencia se ponga en noticia de S.M.".

Como todo lo que atañera a la Iglesia Católica, de la que se consideraba justo y sumiso protector, se consultó esta cuestión con la sagrada persona del rey Carlos III. La consulta se hizo el 12 de septiembre, es decir, después de que las cartas con la providencia acordada por el alto tribunal se hubieran enviado el mismo día 9. Así y todo, se le hizo presente al monarca el resultado del expediente y la decisión propuesta. El rey quedó "enterado". 46

Al arzobispo de Sevilla se le avisó de todo lo acordado, en los términos que decía el informe de los fiscales. A Roque Marín se le comunica también la resolución, que había sido resultado "de las diligencias practicadas" a raíz de las repetidas instancias enviadas.

Al provincial de los dominicos de Andalucía, fray Félix de Alcántara se le comunica, curiosamente, no las conclusiones de la investigación hecha por el arzobispo, sino el resumen que a este mismo se le envió para que elaborara su informe. Así que, tras estos antecedentes, se le señala que "para instruirse el Consejo de estos particulares, tuvo a bien pedir cierto Informe (refiriéndose al del cardenal Solís, sin nombrarle) y con vista de él, ha acordado que se disponga, con la mayor brevedad, mudar a otros conventos de la provincia a dichos lectores...".

El provincial responde al Consejo el 21 de septiembre desde su convento de Marchena (Sevilla). Y dice que, en el mismo correo, remite "los despachos correspondientes a fin de que los lectores del convento de Sanlúcar de Barrameda salgan dentro un breve término para los conventos de Sevilla, Jerez, Osuna y Cádiz", según la orden recibida. Pero emplaza al Consejo a una justificación de todo para comunicarle "la verdad de los hechos" que habían motivado la providencia ${ }^{47}$ con la que no estaba de acuerdo. Acedo.

45 Presidida por Figueroa e integrada por Ávila, Valiente, Azpilcueta y

${ }^{46}$ Así consta en una certificación firmada por Antonio Martínez Salazar, escribano del Consejo, fechada el 10 de Octubre de 1774.

47 Finaliza aquí el expediente abierto por el Consejo sobre este tema. (AHN, Consejos, leg. 904). 
El 5 de octubre de 1774 salieron de Sanlúcar los lectores de Teología fray Francisco Gómez, fray Diego de Almonte, fray Gregorio Cumbreras, fray Agustín Barba, fray Avelino Ruiz, así como el lector de Filosofía, fray Juan de Aguilar. Todos ellos fueron destinados y repartidos entre los conventos ya citados. ${ }^{48}$

\section{RECURSO DEL PROVINCIAL CONTRA LA DECISIÓN.}

Pero fray Félix de Alcántara no se quedó callado y se dispuso a presentar al Supremo Tribunal todos los papeles y justificaciones necesarias para que se revocara una decisión que tanto dañaba "la buena imagen" de su orden. Informó de que el 19 de julio se había abierto ya un proceso eclesiástico de investigación interna para intentar justificar que los desórdenes, el uso de las armas y todas las amenazas contra los priores habían sido una pura invención de los numerosos enemigos de la Iglesia. ${ }^{49}$

El expediente fue reactivado tras la orden de expulsión de los lectores y se continuó posteriormente en otro, iniciado en febrero de 1775 , finalizando en noviembre de $1784 .^{50}$ En el voluminoso expediente atacaron muy duramente al alcalde Marín, al que consideraron culpable de todas las maledicencias esparcidas por la ciudad, fundamentando como origen de todo la gran amistad que unía al alcalde con los dos frailes dominicos, fray Francisco Galisteo y fray Dionisio Ximénez, a quienes la mayoría consideró como "traidores" a su orden, por revelar sus disensiones y enfrentamientos internos "a un magistrado seglar".

Especialmente duras fueron las críticas de fray Juan Moreno -prior en Sanlúcar entre 1766 y 1767-- y de fray Francisco Posadas, lector de

${ }^{48}$ AHN, Consejos, leg. 904, $n^{\circ} 17$ (3), f. 47. No existe constancia del nombramiento de los dos únicos lectores que a partir de entonces estaban autorizados a permanecer en Sanlúcar.

${ }^{49}$ AHN, Consejos, leg. 904, n 17 (3): Pieza de justificaciones hechas en virtud de orden del Provincial de Dominicos de la Provincia de Andalucía, sobre el uso de armas prohibidas y sublevación de los lectores del convento de Sanlúcar de Barrameda. Finalizada la instrucción del expediente, se envió al Consejo para su conocimiento, donde quedó archivado. (61 fols. en total)

$50 \mathrm{AHN}$, Consejos, leg. 904, n 17: Expediente secreto: Respuesta y representación de fray Félix de Alcántara, provincial de dominicos de Andalucía, pidiendo se revoque la orden de destierro de los lectores del convento de Sanlúcar. 190 fols. en total. Este expediente es verdaderamente farragoso, aunque contiene auténticas "joyas" epistolares que relatan con todo detalle el clima de corrupción y relajamiento en el que vivía la provincia dominica andaluza. Aun a pesar de la gran cantidad de diligencias y documentos que abultaron este caso, el Consejo no dio marcha atrás. 
Vísperas en Cádiz y compañero de estudios de fray Dionisio. El primero dice que advirtió en el padre fray Dionisio Ximénez "un genio díscolo, perturbador de la paz, partidario y dominante". No aceptaba "las determinaciones que se daban para el buen régimen y gobierno de la comunidad" que no eran conformes con sus ideas. Así que, "aliado con el padre Galisteo, insultaban y alborotaban el convento, sacando fuera del claustro, a noticia de los seglares, lo que dentro de él pasaba, desfigurándolo y pintándolo a medida de su antojo, con [lo] que se causaron muchas desazones". También quiso influir en él para que falsificara las partidas de gastos del Libro de Caja del convento, diciéndole que era una práctica habitual de los anteriores priores. ${ }^{51}$

Fray Francisco Posadas enumera excesos y delitos cometidos por ambos. ${ }^{52}$ Desde novicio, fray Dionisio Ximénez se había destacado por sus malas costumbres y actos descabellados. Se le castigó en diversas ocasiones, pero volvió a actuar en contra de sus superiores y de las normas. A pesar de todo, se ordenó sacerdote, y desde entonces sus costumbres habían ido "de mal en peor $\mathrm{y}$, por consiguiente, más graves los pesares que ha dado a la religión por culpa de su genio", pues era "chismoso, sembrador de discordias, enemigo declarado de la paz y unión fraterna; falso impostor y calumniador; contra sus prelados, contra sus hermanos religiosos y contra seculares de honor". Fray Francisco Posadas aseguraba que el único lapso de tiempo en que el convento de Sanlúcar había estado apaciguado había sido los cuatro años que fray Dionisio había estado desterrado en Badajoz castigado por sus superiores.

Toda su conducta era la de un consumado hipócrita, pues, fingiendo una gran piedad, humildad y religiosidad, lo único que hacía el padre Ximénez era criticar a todos sus hermanos religiosos, intentando convencer de que él siempre era la víctima de todos los males. Así que cuando estas críticas llegaban a oídos de sus correligionarios y éstos exigían medidas correctivas contra él, enseguida encontraba apoyos entre el pueblo y en diversos seglares distinguidos para librarse de los castigos que le hubieran correspondido.

En todas estas acciones, fray Dionisio encontró siempre como aliado a fray Francisco Galisteo y a su hermano, fray Andrés Galisteo, ambos naturales también de Sanlúcar. Los tres habían tenido "muchos problemas con los priores, cuando éstos no se sometían a sus criterios". Así lo hicieron con fray Juan Moreno y con fray Miguel Caro, pues a éste

${ }^{51} \mathrm{AHN}$, Consejos, leg. 904, n 17, (3), ff. 52 y ss.

52 Ibidem, ff. 54 y ss. 
le habían amenazado "con desvelar sus graves defectos, oídos en secreto de confesión a otro religioso". Igualmente había constancia de que otro de los lectores sanluqueños, el padre fray Antonio Gago, fue amenazado con armas por haberle hecho "una chanza" a fray Andrés Galisteo, hermano del citado fray Francisco, de quien sufrió el acoso, el insulto e incluso la amenaza de agresión física. Un día en que la comunidad había salido, se enfrentó a él "haciendo el ademán como de sacar armas, metiendo la mano bajo el escapulario".

También había desacreditado al ya citado fray Juan Colmenero, lector de Teología, -célebre por sus grandes virtudes religiosas-, hasta conseguir que todo el pueblo le odiara, pues le acusó de mantener relaciones sexuales con una mujer de honor, viuda y con hijos, como de cuarenta años, demostrándose posteriormente que todo había sido una gran patraña. Ya hemos visto la versión que sobre esto dio el arzobispo de Sevilla en su informe. Pues bien, la viuda no estaba embarazada, tal y como aseguraba fray Dionisio, pues se estuvo presentando diariamente en las misas de la iglesia dominica para demostrar que todo era falso.

Por contra, según el padre Posadas, era de todos conocida la amistad que fray Francisco Galisteo mantenía desde hacía varios años con una mujer soltera, cuya casa frecuentaba, y que era tenida en toda Sanlúcar como "de mala opinión y fama". ${ }^{53}$

Pero, sin duda, lo más grave de la declaración de fray Francisco Posadas es la parte referente a la "estrecha amistad" que fray Dionisio y sus partidarios mantenían con Roque Marín, el alcalde mayor, "con quien procedían de común acuerdo". Posadas asegura que "las cartas que Marín dirigía contra los padres lectores eran dictadas por el padre fray Dionisio", y los testigos eran propuestos tanto por este padre como por Galisteo.

Fray Antonio Gago, en su escrito al provincial, ${ }^{54}$ manifestó que el destierro de los lectores había causado un "general sentimiento en las personas juiciosas, tanto dentro de los claustros como fuera, pues notan la falta de obreros para el cultivo de las almas; porque carecen de dirección unos y otros para aprender y perfeccionarse en los fundamentos de la Sagrada Teología, tan necesaria en esta ciudad por la mucha comunicación que por razón del comercio tienen sus habitadores con los protestantes". ${ }^{55}$

53 Ibidem, f. 69.

54 Fechado en Sanlúcar el 20 de enero de 1775.

55 AHN, Consejos, leg. 904, n017 (3), f. 44. En 1786, el síndico procurador presentó al cabildo municipal un informe sobre la decadencia de la enseñanza en la ciudad, proponiendo como remedio el restablecimiento de la 


\section{LARGA JUSTIFICACIÓN DEL PADRE PROVINCIAL.}

Con todas estas noticias, fray Félix de Alcántara escribe una larguísima representación al Consejo para justificar la conducta de los lectores y de su orden. ${ }^{56}$ Procedió luego a nombrar como procurador de la provincia andaluza a uno de los expulsos, el lector fray Diego de Almonte, a la sazón en Madrid, para que en su nombre pudiera representar los derechos de la orden "ante el Rey Nuestro Señor y Señores de su Real y Supremo Consejo de Castilla, y demás Tribunales y Juzgados", con el fin de conseguir "la restitución" de los desposeídos de las cátedras del convento de Santo Domingo. ${ }^{57}$

Diego de Almonte, una vez recibida la comisión, procedió de inmediato a buscar sustitutos y encontró a dos procuradores profesionales, acostumbrados a litigar entre los pasillos de los Consejos de la Corte con toda clase de asuntos. ${ }^{58}$

Uno de estos procuradores se dispuso inmediatamente a ganarse a pulso el puesto y presentó al Consejo una petición para que se revisase la causa. El procurador Melendreras introdujo una cuestión sorpresiva en el expediente pues alegó que todo el revuelo formado en Sanlúcar estaba basado en la "coligación" del suprior Galisteo, fray Dionisio Ximénez y el alcalde mayor, cuando procedieron sin permiso a trasladar la reja de la capilla del Rosario de la iglesia conventual. Y que todo había sido producto de una voz o rumor interesado al que el alcalde mayor había prestado oídos para tapar el escándalo de la traslación de la reja. Y que cuando el gobernador Quintana había tratado de parar esa voz y esclarecer la verdad, Roque Marín se opuso y consiguió neutralizar la carta que el gobernador iba a enviar al Consejo en la que descargaba

Escuela dominica, pues su supresión "por fines particulares" había causado "graves perjuicios a la causa pública, además de dañar sensiblemente a la comunidad dominica" y al culto divino que se realizaba en su templo, que cada vez había ido a menos. (Narciso CLIMENT: Historia social de Sanlúcar...T. 4, pp. 376-377)

${ }^{56}$ Seguimos en AHN, Consejos, leg. 904, nº 17.

57 Poder fechado el 25 de febrero de 1775 (AHN: Consejos, 904, n 17, ff. 21 y ss.).

58 El 7 de Marzo del mismo año delegó en Francisco Antonio Melendreras y Andrés Maján Moreno, procuradores de los Reales Consejos (AHN, Ibidem, f. 22v). 
de culpa a los lectores dominicos, "verdaderamente inculpables e inocentes". 59

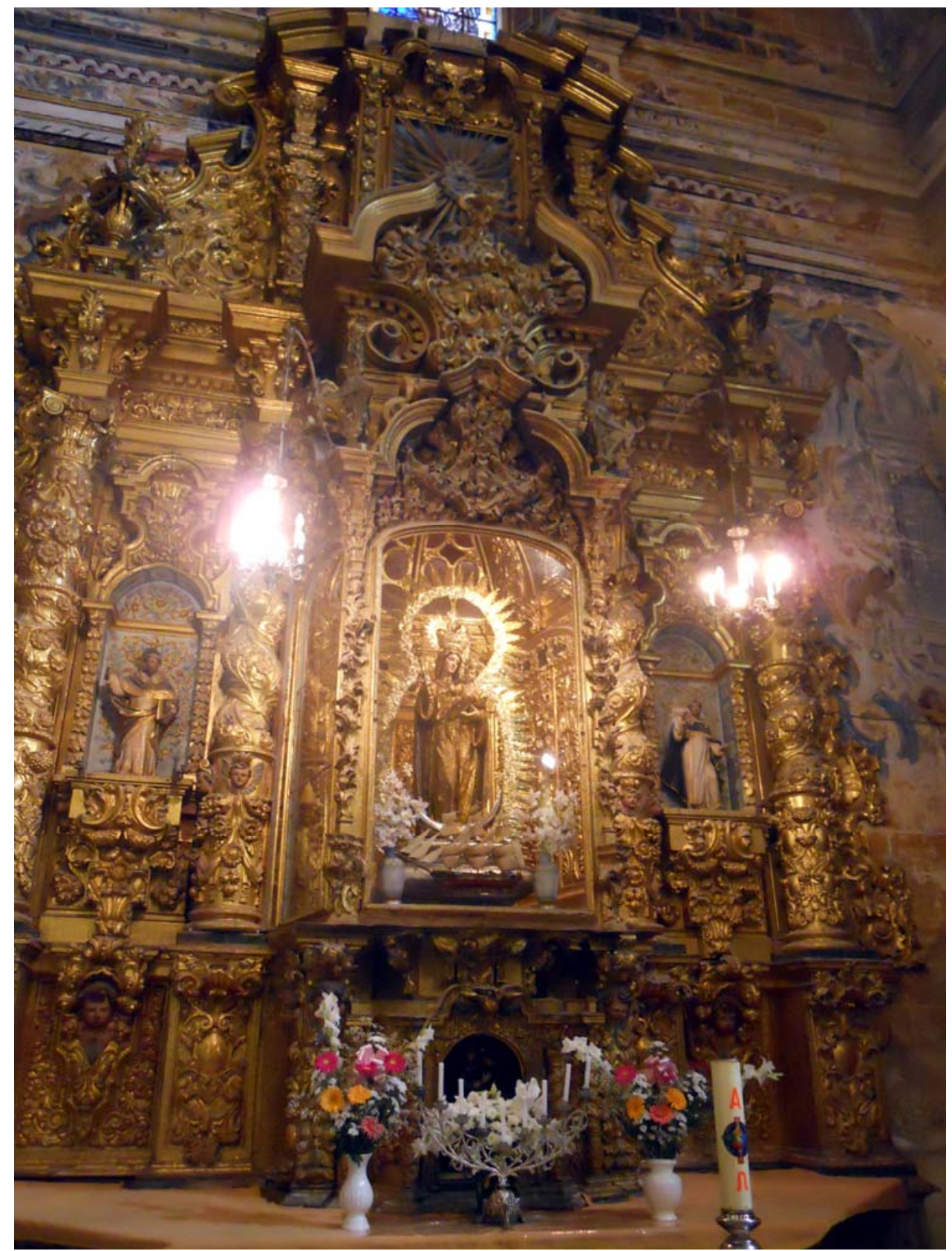

Figura 2. Retablo de la capilla de la virgen del Rosario en el convento dominicano (Fotografía del autor)

Los dominicos andaluces ignoran que la decisión del Consejo no es producto únicamente de las denuncias de Roque Marín sino también del informe enviado por el arzobispo de Sevilla, según se ha dicho más arriba. Se aventuran a culpar al alcalde de unos hechos no probados judicialmente. Se dejan llevar por rumores. Aunque, en el asunto de la carta del gobernador Quintana interceptada por Roque Marín, las

\footnotetext{
${ }^{59}$ AHN, Ibidem, f. 23v.
} 
posteriores declaraciones escritas de los protagonistas del incidente darán la razón a los lectores.

El procurador pedía pues la restitución de los lectores a sus puestos, pues eran "de recomendable conducta, celo y aplicación, y como a tales les estima el Pueblo y siente su ausencia". ${ }^{60}$

Roque Marín, sabedor de estas gestiones en la Corte, se apresura a redactar al Consejo una nueva exposición para pedirle que se resista a las fuertes presiones que intentan convencerle para que corrija la grave decisión tomada. Los dominicos habían cumplido la determinante orden del Consejo a medias, pues seguían manteniendo las celdas de los lectores expulsos en iguales condiciones que antes de marcharse, sin despojarlas de sus muebles y pertenencias. Estaban divulgando por Sanlúcar que muy pronto volverían a ser ocupadas por sus legítimos propietarios, cuando el Consejo reconsiderara su decisión. Todas las advertencias que se le habían hecho al prior habían resultado nulas, pues, según informa el alcalde, era el propio provincial el que había ordenado que no se desalojasen las celdas de los expulsos.

Otro de sus argumentos fue que los lectores desterrados estaban moviéndose, con el provincial, para organizar la defensa de la orden. Sabía ya Marín que fray Diego de Almonte había salido el 17 de febrero desde Osuna con dirección a la Corte, con la intención de pleitear en el Supremo Consejo de Castilla.

Entre los graves acontecimientos de estos meses y en el curso de la investigación judicial abierta, se demostró que un número importante de dominicos tenía en sus celdas, bien escondidas en los armarios, armas de fuego, tales como escopetas y pistolas. Quedó acreditado cómo algunos lectores, desde hacía años, salían del convento a altas horas de la noche, sin permiso alguno de su superior y que incluso dormían fuera del convento. También quedó en entredicho la moralidad y la castidad de algunos de ellos, a quienes se acusó incluso de haber mantenido relaciones carnales y haber dejado embarazadas a varias mozas sanluqueñas. ${ }^{61}$

De todo lo expuesto, por otra razón que no sea la simultaneidad en el tiempo y la coincidencia de ser el alcalde mayor, Roque Marín, el juez de una causa tan problemática como la abierta contra el homicida fray

\footnotetext{
${ }^{60}$ AHN, Ibidem, f. 25 y ss.

${ }^{61}$ AHN, Consejos, leg. 904, 17 (4). Pueden verse, por ejemplo, los folios 104 y ss.
} 
Pablo de San Benito, no puede deducirse desde la información suministrada en los documentos, la relación directa entre el alboroto de los dominicos y el proceso criminal contra el carmelita descalzo. Ni siquiera considerando lo revueltos que estaban los tiempos en las relaciones Iglesia-Estado, desde la expulsión de los jesuitas y el ambiente general de crispación que existía entre los eclesiásticos por lo que consideraban una seria, grave e injusta amenaza contra sus crecidos y ancestrales privilegios e inmunidades.

Aunque pueda ser descartada una hipotética conspiración de los regulares contra el alcalde mayor, unos interesantes documentos arrojan bastante luz sobre lo tensas que estaban las relaciones entre Roque Marín y el convento de los dominicos de Sanlúcar. ${ }^{62}$ Esta documentación ilustra muy bien sobre la manera en que estos frailes buscaron la implicación del duque de Medina Sidonia en el asunto, para tratar de ponerlo de su parte ante el Consejo y ante Carlos III. Pedro Alcántara de Guzmán, residente entonces en la Corte de Madrid, fue el decimocuarto duque y el último de la dinastía de los Guzmanes antes de que el título pasase, por haber muerto sin descendencia, a los Álvarez de Toledo. ${ }^{63}$ La casa ducal seguía ostentando el patronato de diversos conventos e iglesias de Sanlúcar, entre ellos el de Santo Domingo y el de la Merced descalza. ${ }^{64}$ Las tres cartas cruzadas entre el duque y Francisco de Almadana y Ordiales, regidor municipal y administrador ducal en la ciudad, ${ }^{65}$ permiten conocer lo que parece haber sido el germen del conflicto entre alcalde y la orden dominicana, así como la evolución posterior de la resolución del Consejo respecto a la expulsión de los lectores de Sanlúcar. ${ }^{66}$

62 Manuel BARBADILLO, Olvidos históricos, Jerez 1977, pp. 113-114.

${ }^{63}$ Aún a pesar de que la Casa ducal había perdido la posesión del señorío de Sanlúcar en 1645, era aún el mayor propietario en la ciudad. Pedro Alcántara, que falleció en 1777, era hijo de Domingo José Claros Pérez de Guzmán y de Josefa Pacheco y Moscoso.

64 La casa ducal conservaba en esta última orden el Patronato General de ella y por tanto, el privilegio de designar la "asignación de casa y convento" en la que debían celebrar su Capítulo General los mercedarios de España cada seis años. Dicho capítulo tendría lugar, alternativamente, una vez en Castilla y otra en Andalucía. Así lo hizo Josefa Pacheco, madre y "curadora" del joven duque Pedro de Alcántara en un documento fechado en Huelva el 20 de Noviembre de 1740. (Biblioteca de la Universidad de Sevilla, Fondo Antiguo: Asignación de casa... Signatura 332/124).

${ }^{65}$ Almadana y Ordiales fue recibido como regidor perpetuo del cabildo el 3 de Marzo de 1768. Tenía su asiento pues, en el cabildo municipal, siendo "compañero de corporación" del alcalde Roque Marín durante los años que nos ocupan. (Pedro BARBADILLO DELGADO, Historia de Sanlúcar de Barrameda. Cádiz 1942, pp. 491 y 945)

${ }^{66}$ Las cartas originales se conservan en el Archivo de la Fundación 
En la primera carta, fechada en Madrid el 7 de marzo de 1775, a los seis meses de la resolución del Consejo, el duque informa a su tesorero sanluqueño que "el provincial de dominicos de Andalucía ha producido $^{67}$ en el Real Consejo de Castilla una larga representación, dirigida a que se alce ${ }^{68}$ el destierro de los padres lectores" que se había decretado "a consecuencia de las quejas dadas" por el gobernador y por el alcalde mayor sanluqueños.

En esta comunicación se desvela el contenido de la solicitud que fray Félix de Alcántara envió al Consejo. El padre provincial de los dominicos atacó con furor al alcalde mayor, acusándolo de parcialidad y de ser enemigo de su orden. El origen de todo había sido una actuación de Roque Marín en la misma iglesia del convento, en su calidad de mayordomo de la cofradía del Rosario, sin los permisos necesarios del mismo provincial y del duque, patrono del convento:

"En ella se expone -dice el Medina Sidonia- que el alcalde mayor hizo sacar la reja de la capilla mayor de la Iglesia de dicho convento [de Santo Domingo], unas cuantas varas del sitio en que antes estaba, no obstante haberle prevenido que dicho convento era Patronato de mi Casa y que sin mi licencia, no se podía alterar la positura ${ }^{69}$ de la citada reja".

Reconoce el duque su gran influencia en la Corte y que, por esta circunstancia, los dominicos buscan su ayuda para que el Consejo admitiera su recurso. Por todo ello, le solicita a Almadana y Ordiales que le informe sobre el asunto de la reja, "dejando aparte las demás quimeras de los religiosos, que nada me tocan". ${ }^{70} \mathrm{Y}$ añade que, una vez bien informado del asunto, determinará lo que mejor le parezca "sobre la solicitud del reverendo provincial".

Recuerda también a Almadana que aún estaba esperando "el informe sobre el religioso dominico de esa ciudad que se me ha

Casa Ducal de Medina Sidonia (ADMS), en el leg. 2394.

${ }^{67}$ Producir: (Der.) Dicho de una persona: Exhibir, presentar, manifestar a la vista y examen aquellas razones o motivos o las pruebas que pueden apoyar su justicia o el derecho que tiene para su pretensión.

${ }^{68}$ Alzar: Levantar, quitar. Apelar, recurrir a juez o tribunal superior.

${ }^{69}$ Positura: Postura, posición o estado.

70 Tocar: Pertenecer por algún título o ser de la obligación o cargo de uno. Pertenecer parte de una cosa que se reparte, o caer en suerte una cosa. Importar, ser de interés. 
presentado aquí". ${ }^{71} \mathrm{El}$ duque no quiere "mezclarse en frioleras". ${ }^{72}$ Es de suponer que este religioso no era otro sino el padre Diego de Almonte, que, como hemos explicado, viajó hasta Madrid para defender a la orden dominica ante el Consejo. El duque lo califica de "vivo", ${ }^{73}$ y reconoce en él la intención oculta de que la casa ducal haga causa común con su orden religiosa, recurriendo a la ayuda e influencias del duque. Desde luego, los religiosos sanluqueños no se cruzaron de brazos ante la drástica resolución del Consejo de suprimir las cátedras del convento sanluqueño.

El 14 de marzo, responde el administrador Almadana al duque, ${ }^{74}$ prometiéndole que hará una "menuda inspección de lo sucedido" sobre el cambio de la reja de la capilla. No se había extrañado de que el alcalde mayor no hubiera pedido permiso para cambiar la reja de sitio pues, según su opinión, Marín era "poco político y nada jurista, y por tanto piensa que siendo juez tiene bastante para mandar hasta en lo sagrado".

Todo el expediente sobre los dominicos había sido un asunto exclusivamente promovido por el alcalde mayor, pues el gobernador Miguel de Quintana no había tenido nada que ver. ${ }^{75}$ Éste había manifestado en alguna ocasión que el alcalde mayor era "el más pésimo que en esta ciudad se ha experimentado". ${ }^{76}$

El administrador Almadana, tras las oportunas averiguaciones, aclara un semana después que la reja "mudada" no era la de la capilla o altar mayor, como decía el duque, sino la de la capilla de la Virgen del Rosario. El motivo fue por haber nombrado la Hermandad como uno de sus mayordomos al alcalde mayor. ${ }^{77}$ La reja de esta capilla ya se quitó

${ }^{71}$ Manuel BARBADILLO, Op. cit., p. 113.

72 Friolera: Cosa de poca monta o de poca importancia, aunque puede usarse en sentido irónico para querer decir todo lo contrario.

${ }^{73}$ Vivo: Sutil, ingenioso. Listo, que aprovecha las circunstancias y sabe actuar en beneficio propio. Demasiado audaz en las expresiones o las acciones.

${ }^{74}$ ADMS, leg. 2394.

${ }^{75}$ El 19 de Enero de 1775 se dio sepultura al gobernador Quintana (ADMS, leg. 2394: Carta del administrador Almadana al duque de Medina Sidonia, Sanlúcar, 20-I-1775)

${ }^{76}$ Aún a pesar de estas reiteradas críticas, Roque Marín pasaría a ser alcalde mayor de Cádiz, Jijona, Daroca y, muy poco tiempo después, de Alicante (Enrique GIMÉNEZ LÓPEZ: "Caballeros y letrados. La aportación civilista a la administración corregimental valenciana durante los reinados de Carlos III y Carlos IV". En Revista de Historia Moderna: Anales de la Universidad de Alicante. № 8-9, 1988-1990, pp. 167-182.)

77 La Hermandad del Rosario del Convento de Santo Domingo era una 
"en tiempos de don Bartolomé Moreno", 78 pero se puso de nuevo a petición de José García de Poedo. ${ }^{79}$ Más tarde, se volvió a sacar la reja del altar mayor, interviniendo el marqués de Campoameno, yerno de García de Poedo, viviendo éste, "sin que a mí me conste si precedió para ello el beneplácito de V.E.", dice Almadana al duque.

Son conocidos los frecuentes roces y disputas entre los miembros de las órdenes religiosas que regentaban las iglesias conventuales y los dirigentes seglares de las hermandades y cofradías establecidas en ellas. ${ }^{80} \mathrm{Y}$ aunque el hecho, convenientemente ocultado por Roque Marín,

poderosa hermandad en la época que gozaba de bastantes bienes. En el AHN (Clero, leg. 1738) se conservan algunos expedientes de estos bienes.

78 Bartolomé José Moreno fue un anterior administrador del duque en Sanlúcar.

79 García de Poedo era, desde 1747, uno de los nobles o hidalgos reconocidos por la Ciudad. Fue también familiar de la Inquisición (1734) y cinco años más tarde, compró el oficio de regidor en el cabildo municipal. A su muerte, sus herederos vendieron el oficio a Almadana, precisamente, en el año 1767. (Pedro BARBADILLO DELGADO, Op. cit., pp. 491, 928 y 939). Como podemos comprobar por el propio texto, el célebre marqués de Campoameno, Juan Pedro Velázquez Gaztelu, casó con una hija de García de Poedo. El marqués, por otra parte, había sido el anterior administrador del duque en Sanlúcar (hasta 1771).

${ }^{80}$ Salvador DAZA PALACIOS: "Pleito entre carmelitas: Frailes calzados y descalzos de Sanlúcar de Barrameda en litigio por la Hermandad del Carmen". En la Rev. Sanlúcar de Barrameda, 2012, pp. 130-137. Narciso CLIMENT BUZÓN: Historia social de Sanlúcar de Barrameda: en busca de nuestro pasado (1700-1759). Sanlúcar, 2008, T. 3, pp. 332: Los frailes mínimos de San Francisco de Paula pusieron en la calle violentamente, expulsándolos de la iglesia de su convento, a los cofrades de la Hermandad de las Angustias. N. CLIMENT: Historia social... (1759-1833), Sanlúcar, 2009, T. 4, p. 77 y 644: Pleito entre la Hermandad del Nazareno y el convento de San Agustín sobre la propiedad de unos varales de plata del paso de la Virgen. AHN, Consejos, leg. 1575, $n^{\circ}$ 43: El mayordomo de la cofradía de Jesús Nazareno contra el convento de San Agustín, donde radica, sobre la aprobación y arreglo de sus ordenanzas. AHN: Inquisición, 3725, exp. 258: Pleito de la Congregación de San Pedro Mártir de Zaragoza contra el prior y convento de dominicos de dicha ciudad. AHN: Consejos, 1452, Exp.1: Expediente iniciado de oficio por el Consejo a causa de los desórdenes y excesos ocurridos en 1770 en la procesión de la imagen de la Consolación del Convento de Mínimos de San Francisco de Paula extramuros de la villa de Utrera. AHN, Consejos, 7090, Exp.1 (Fol.90 y ss.): Expediente iniciado por el gobernador de Ciudad Rodrigo, sobre los desórdenes y excesos que provoca la cofradía de la Santa Veracruz fundada en el convento de San Francisco Extramuros de Ciudad Rodrigo. 25 de febrero de 1771. 
de que ostentaba la administración y regencia de esta cofradía dominica pueda causar admiración y extrañeza, sorprende aún más el resto del relato. El alcalde mayor, "intentando dorar el altar" de la virgen del Rosario y ampliarlo sacándolo más afuera, hizo lo mismo con la reja, "por parecerle [que] estorbaba en la estrechez que quedaba".

Velázquez Gaztelu describe la situación de la reja de la capilla del Rosario de la Iglesia de Santo Domingo, la que, al parecer, formaba un cuerpo único con las del altar mayor y la de la capilla del Dulce Nombre de Jesús, situadas a ambos lados de la capilla central, ofreciendo "una impresionante visión de grandeza". ${ }^{81}$

El traslado de la reja ocurrió, según los datos ofrecidos por nuestro informante, entre el cuatro y seis de julio de $1773,{ }^{82}$ fecha en la que el retablo de la capilla del Rosario salió del convento de Santo Domingo, suponemos que de camino hacia el taller de dorado. Tuvieron que desmontar la reja para sacar el altar y el retablo. Cuando Almadana envía su informe la reja no se había colocado todavía.

La grada o escalón de acceso a la capilla se sacó una vara ${ }^{83}$ hacia la nave central de la iglesia. Pero ni para esta operación ni para las demás se contó con la licencia del provincial, que ya se la había denegado al anterior mayordomo de la cofradía, Josef de la Peña y a sus hermanos mayores Luis de Valderrama y Gabriel de Costas, "cuando estuvo de visita en este convento en el mes de Noviembre de 1772. Así que para mudar la reja y sacar la capilla del Rosario esperaron que "el padre prior estuviera ausente en El Puerto de Santa María". Pero no la quitó el maestro albañil, "como han supuesto, porque fue a la hora de comer, sino los padres fray Dionisio Ximénez, fray Francisco Galisteo, fray Andrés Galisteo y el hermano Álvaro Moreno, sacristán menor". El alcalde y nuevo mayordomo, Roque Marín, informó por escrito al provincial sobre lo sucedido, haciéndole creer que había sido "una tramoya ${ }^{84}$ hecha por el albañil y no por él ni por los padres".

81 Juan Pedro VELÁZQUEZ GAZTELU, Fundaciones..., p. 210. Fernando GUILLAMAS GALIANO, Historia de Sanlúcar de Barrameda, Madrid 1858 , p. 85. Ninguna de estas rejas existe en la actualidad, excepto una pequeña barandilla que protege el escalón de entrada a la capilla del Rosario.

${ }^{82}$ Manuel BARBADILLO, Op. Cit., p.114.

${ }^{83}$ Vara: Medida de longitud, equivalente en Castilla a 835 milímetros y 9 décimas. Dividida en tres pies o cuatro palmos. La grada se refiere al escalón que da entrada a la capilla. En el plano adjunto se puede ver la variación.

${ }^{84}$ Tramoya: (fig.) Enredo dispuesto con ingenio, disimulo y maña. El tramoyista es el encargado de los cambios de decorado en el teatro. Es utilizado aquí el término de forma muy curiosa, como sinónimo de cambio escénico o transporte de decorado. 
El provincial de los dominicos respondió al alcalde mayor "con bastante acrimonia", ${ }^{85}$ por haber sido una "acción ejecutada sin su licencia" y por haberse dado cuenta de que la maniobra del alcalde había sido producto de "no haber querido condescender a lo que le pidieron los mencionados mayordomo y hermanos mayores" en su primera solicitud. ${ }^{86}$

La versión de esta carta, que ofrece Barbadillo, difiere de la original que obra en el Archivo Ducal, pues el escritor omitió el siguiente párrafo: "Indudablemente, se le previno [al alcalde mayor], por algunos religiosos, que se necesitaba impetrar el beneplácito de V.E. para la mudada del altar y reja". Pero Roque Marín no hizo caso ni se entretuvo en realizar este necesario trámite sino que solicitó la venia una vez ejecutada ya la traslación de la reja. ${ }^{87}$

La información remitida al duque por Almadana concluye felicitándole por la intención que manifestaba en su carta "de no inmiscuirse en el asunto de los religiosos que pende en el Consejo", pues no tenía dudas de que "entre ellos había discordia". Una discordia que, en opinión del administrador, podía haber remediado a tiempo el provincial destinando a los lectores rebeldes a otros conventos.

El duque respondió desde Aranjuez, el 31 de marzo de 1775.

"Quedo enterado de lo ocurrido..., y aunque la mutación hecha en su iglesia ha sido de corto momento, creo que el señor Alcalde mayor no hubiera quedado desobligado de mi atención, si le hubiese debido la [cortesía] de avisarme antes de ejecutarla" ${ }^{88}$

No tenemos más datos sobre el fin de este negocio, que duró hasta 1784. Lo cierto es que el retablo de la capilla de la Virgen del Rosario se doró y restauró, realizándose su inauguración, según consta en una lápida conmemorativa situada en uno de sus laterales, hacia octubre de $1773^{89}$.

85 Acrimonia: Calidad de acre. Aspereza en el trato. Acre: Dícese del lenguaje áspero y desabrido.

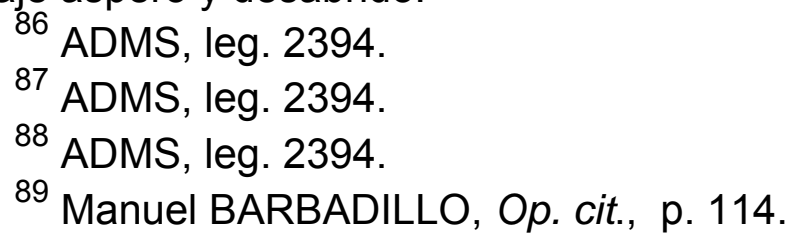


Es evidente que los dominicos intentaron aprovechar este desliz del alcalde mayor para cargar contra él por considerarle culpable de la decisión del Consejo de Castilla de eliminar prácticamente la Escuela de Teología que venía funcionado desde hacía más de dos siglos. Aunque no existe una relación directa entre estos hechos, dado que el asunto de la traslación de la reja de la capilla se produjo casi un año antes de los graves acontecimientos reflejados en el expediente de expulsión de los lectores dominicos, influyó sin duda en la mala relación entre el juez y el padre provincial. Pero fue el arzobispo de Sevilla el último responsable de la supresión de las cátedras de los lectores sanluqueños.

Según Guillamas, la Escuela de Artes y Teología (o lo que quedó de ella) siguió abierta hasta el año 1808 y sus estudios "dieron muy buen resultado" tanto a los estudiantes dominicos, "como a todos los hijos de la ciudad que querían asistir a sus lecciones". ${ }^{90}$ Pero esta falsa referencia no está completa. Procede de una información recogida en la obra de Velázquez Gaztelu, en la que el ilustrado sanluqueño se lamentaba, ya hacia 1758, del "gran descaecimiento ${ }^{91}$ que tiene hoy el crédito de esta enseñanza, comparado con el siglo pasado". Las razones de esta crisis las sitúa el historiador en la procedencia de los lectores, maestros y priores que ejercían la autoridad en este convento, casi todos forasteros, que no tenían a la ciudad el mismo amor que los naturales: "... y de aquí la decadencia en la sólida virtud, el buen régimen de la doctrina y [la] regularidad monástica". ${ }^{92}$

Dieciséis años después de que Velázquez Gaztelu redactase estas palabras la situación no había cambiado. Incluso se agravó. No eran muchos, según parece, los que querían asistir a recibir instrucción de los dominicos, según el testimonio del mismísimo cardenal Francisco de Solís. Su supresión no iba a causar mayores o más graves problemas de los que ya habían creado en Sanlúcar los lectores con su presencia y su irregular, inmoral e impetuoso comportamiento.

\footnotetext{
90 Fernando GUILLAMAS GALIANO, Op. cit., p. 85.

91 Descaecimiento: Debilidad, flaqueza, falta de fuerzas y vigor en el cuerpo o en el ánimo.

92 J. P. VELÁZQUEZ GAZTELU, Fundaciones...., p. 207.
} 
ANEXO:

LÁPIDA CONMEMORATIVA EXISTENTE EN LA CAPILLA DEL ROSARIO DE LA PARROQUIA DE SANTO DOMINGO. ${ }^{93}$

\author{
"SIENDO MAYORDOMO DE LA COFRADÍA \\ DEL SANTÍSIMO ROSARIO EL SR. D. ROQUE \\ MARÍN DOMÍNGUEZ, ABOGADO DE LOS REALES \\ CONSEJOS, ALCALDE MAYOR POR S.M. \\ Y CORREGIDOR INTERINO ${ }^{94}$ DE ESTA CIUDAD \\ Y HERMANOS MAYORES LOS SEÑORES \\ JOSEPH DE LA PEÑA, Y D. JOSEPH DEL CASTILLO, \\ SE DORÓ EL RETABLO DE NTRA. SRA. \\ Y SE PINTÓ Y ADORNÓ SU CAPILLA \\ A SU SOLICITUD Y ESMERO, CON LIMOSNAS \\ DE LOS HERMANOS Y DEVOTOS. \\ AÑO DE 1773".
}

93 La lápida se conserva en un estado relativamente bueno y su inscripción usa la típica escritura abreviada.

94 El hecho de que Roque Marín rece en la inscripción como corregidor indica que la lápida, a pesar de figurar el año de 1773 en ella, —año del arreglo del retablo-, no se colocó hasta después del 18 Enero de 1775, día en el que Marín tomó posesión del puesto de corregidor, por haber fallecido el gobernador Quintana. 


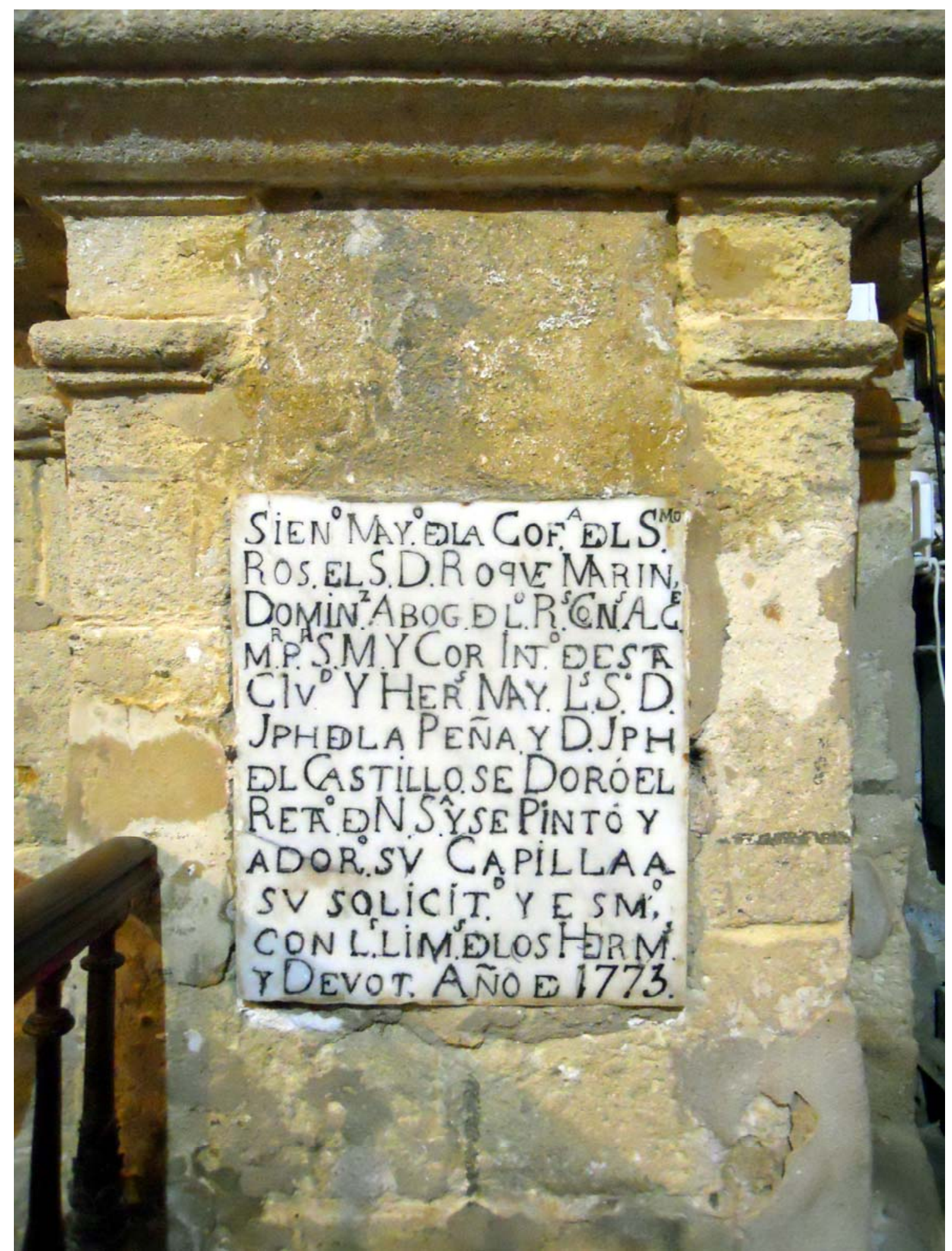

Figura 3. Lápida conmemorativa del dorado del retablo de la virgen del Rosario, colocada en la época en que fue su mayordomo el alcalde mayor Roque Marín (Fotografía del autor). 
DOCUMENTACIÓN:

ARCHIVO HISTÓRICO NACIONAL,

- Consejos, leg. 904, $\mathrm{n}^{\circ} 17$.

-Clero, leg. 1738.

BIBLIOTECA DE LA UNIVERSIDAD DE SEVILLA, Fondo Antiguo:

-Real cédula de S.M. y señores del Consejo, que comprehende las actas de reducción de religiosos del Orden de Mercedarios descalzos de estos reynos (1774) Signatura: A 113/135 (15).

-Real cédula de S.M. y señores del Consejo, que comprehende las actas de reducción de religiosos del real y militar orden de Mercenarios Calzados de estos reynos (1774) Signatura: A 113/135 (19).

-Asignación de casa en que ha de celebrarse el Capítulo General de la Orden de la Merced en 1741 Signatura: A 332/124, ff. 351-352.

\section{ARCHIVO DE LA FUNDACIÓN CASA DUCAL DE MEDINA SIDONIA,} -Leg. 2394.

\section{BIBLIOGRAFÍA}

Barbadillo Delgado, Pedro: Historia de Sanlúcar de Barrameda. Cádiz 1942.

Barbadillo, Manuel: Olvidos históricos, Jerez 1977.

Briasco Urgell, $\mathrm{M}^{\mathrm{a}}$ Victoria y otros: Inventarium: dominicos andaluces, oficios y ordenaciones. Málaga 1985. 1989.

Callahan, William J.: Iglesia, poder y sociedad, 1750-1874, Madrid,

Climent Buzón, Narciso: Historia social de Sanlúcar de Barrameda: En busca de nuestro pasado. Cual lapa aferrada al Antiguo Régimen (1700-1759). T. 3, Sanlúcar, 2008.

Climent Buzón, Narciso: Historia social de Sanlúcar: En busca de nuestro pasado. Entre sombras ilustradas y miedo a la libertad (17591833) T. 4, Sanlúcar, 2009. 
Cuesta Mendoza, Antonio: Los dominicos en el Puerto Rico Colonial, 1521-1821. México 1946.

Daza Palacios, Salvador y Prieto Corbalán, María R.: Proceso criminal contra fray Pablo de San Benito en Sanlúcar de Barrameda. Univ. de Sevilla, 1998.

Daza Palacios, Salvador y Prieto Corbalán, María R.: "El proceso contra fray Pablo de San Benito en Sanlúcar de Barrameda, primer proceso de la justicia civil española contra un eclesiástico homicida". En III Jornadas de Castilla-La Mancha de Investigación en Archivos: La Administración de Justicia en la Historia de España, Actas. Guadalajara 1999. T, I, pp. 119-140.

Daza Palacios, Salvador y Prieto Corbalán, María R.: "La justicia en la época de Carlos III, a través de un célebre proceso criminal", en Archivo Hispalense, $\mathrm{n}^{\circ}$ 241, 1996, pp. 47-67.

Daza Palacios, Salvador: "Acontecimientos extraordinarios en la ciudad de Llerena (1768-1773)". Revista de Estudios Extremeños, LVI (Mayo-Agosto 2000), 523-542.

Daza Palacios, Salvador: "La fallida mudanza de los carmelitas descalzos de Sanlúcar de Barrameda (1774)". Art. inédito.

Daza Palacios, Salvador: "Pleito entre carmelitas: Frailes calzados y descalzos de Sanlúcar de Barrameda en litigio por la Hermandad del Carmen”. En la Rev. Sanlúcar de Barrameda, 2012, pp. 130-137.

Ferrer Benimelli, José Antonio (Ed.): Relaciones Iglesia-Estado en Campomanes. Madrid, 2002.

Giménez López, Enrique : "Caballeros y letrados. La aportación civilista a la administración corregimental valenciana durante los reinados de Carlos III y Carlos IV". En Revista de Historia Moderna: Anales de la Universidad de Alicante. № 8-9, 1988-1990, pp. 167-182.

Guillamas Galiano, Fernando: Historia de Sanlúcar de Barrameda, Madrid, 1858.

Huerga, Alvaro : Los dominicos en Andalucía. Sevilla, 1992.

Llombart Rosa, Vicente: Campomanes, economista y político de Carlos III, Madrid, 1992.

Nieser Albert Bertrand : Las fundaciones misionales dominicas en Baja California, 1769-1822. Universidad Autónoma de Baja California, 1998.

Sarrailh, Jean: La España ilustrada de la segunda mitad del siglo XVIII, Madrid, 1992. 
Tomás y Valiente, Francisco: "Campomanes y los preliminares de la desamortización eclesiástica", en Gobierno e instituciones en la España del Antiguo Régimen. Madrid, 1982, pp. 287-316.

Velázquez Gaztelu, Juan Pedro: Fundaciones de todas las iglesias, conventos y ermitas de Sanlúcar de Barrameda (1758), Sanlúcar, 1995. 